\title{
Rearing conditions and sociability in Lebistes reticulatus
}

\author{
GEORGE A. PINCKNEY AND LINDA E. ANDERSON \\ STATE UNIVERSITY OF NEW YORK COLLEGE AT BROCKPORT
}

Sociability behavior in guppies reared in isolation was compared with that of guppies reared in groups. Results indicated that isolation reared Ss tended to avoid other fish early in the testing phase of the experiment, but spent an increasing amount of time near them as the experiment progressed. Group reared Ss, on the other hand, spent a great deal of time in the presence of display animals early in the experiment, but spent less time there on subsequent testing.

The effect of early experience on later sociability has been investigated in a wide range of species. These include the dog (Elliot \& King, 1960), the monkey (Harlow, 1958), and the duck (Hess, 1957). More recently Lindzey, Winston \& Roberts (1965) have investigated the relationship between genetic differences and sociability in five highly inbred strains of mice, their measure of sociability being the time spent near cages containing display animals in an open field. They found significant strain differences, and their results suggested that the least fearful strains were the most sociable.

Shelley \& Hoyenga (1966) employed the methodology of Lindzey, Winston, and Roberts in a study of rearing conditions and sociability in the white rat. Their results indicated that group reared and isolation reared subjects initially spent about the same amount of time adjacent to display animals, but over successive days the isolation reared subjects spent more time near the display animals, while the group reared subjects spent less time there.

The present study was designed to investigate the effects of isolation and group rearing conditions on later sociability in fish, more specifically the guppy, Lebistes reticulatus. The fish seemed an ideal organism for such a study since they display a good deal of social behavior, and live bearing species such as the guppy are independent of their parents from birth.

Method

The Ss for this study were 32 guppies, Lebistes reticulatus, born of stock obtained from a local dealer. Immediately upon birth, a total of 50 fry were taken from their parents and placed in special tanks prepared for the present experiment. One-half of the Ss were placed in individual 2-1/2 gallon glass aquaria, while the other half were placed in two 10 gallon aquaria. They were raised on twice daily rations of frozen shrimp and a prepared day flake food. At the end of two weeks, the group reared Ss were separated by sex.

An aquatic open field, 24 in. $\times 24$ in. $x 6$ in., was used for testing. A glass display tank, 6 in. $x 6$ in. $x$ 6 in. was placed in each corner of the open field, with a line painted on the floor 2 in. from the two exposed sides of the display tanks. The entire apparatus was housed in a plywood shell, with observations made through one-way glass set in the top of the housing. Illumination was provided by a $25 \mathrm{~W}$ bulb contained in a stainless steel aquarium reflector and mounted to the inside roof of the housing.

Five male and five female guppies were used as display animals, and were placed in the display tanks with the males diagonally opposite from the females. The other two display tanks were empty. The positions of the display tanks were systematically rotated for each session of the experiment. Ss were tested at the age of 6 months for seven daily sessions. In each session, $S$ was placed in the center of the open field and allowed to swim freely for 5 min. During this period, an observer recorded the number of sec $\mathrm{S}$ spent adjacent to each of the four display tanks. $\mathrm{S}$ was judged adjacent to a display tank if the forward half of his body was over the line drawn around the tank. A total of 16 males and 16 females was randomly selected for testing from the original group of 50 fry. Eight of each sex were from the isolated fish, and eight were from the group reared fish.

Results

The mean number of seconds which each of the two groups spent near the display animals on each of the seven days of the experiment is shown in Fig. 1. Analysis of variance of these data indicated that the effect of rearing conditions was not significant $(F<1)$, while significant effects were found for days $(F=6.32$, $\mathrm{p}<.001$ ), as well as for the days by rearing conditions interaction ( $F=8.98, p<.001)$.

Further examination showed that the group reared Ss spent a decreasing amount of time near the display animals over the course of the experiment. This decline in time from Day 1 to Day 7 was significant at the .001 level $(t=6.94)$. The isolation reared $\mathrm{Ss}$, on the other hand, showed a significant increase in time spent near the display animals from Day 2 to Day 5 $(t=4.21, p<.05)$.

The possibility that the experience of being reared with members of the same sex might have an effect on the sociability behavior of Ss was examined by dividing the total time spent near display animals into the time spent near animals of the same sex and time spent near animals of the opposite sex. Analysis of variance revealed that group reared Ss spent sig- 


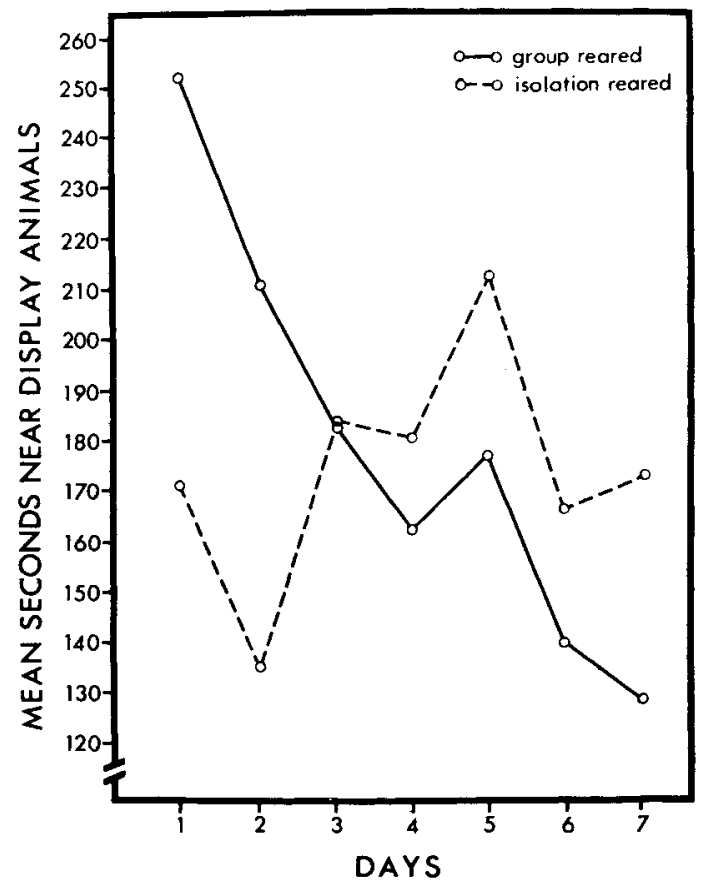

Fig. 1. Mean number of seconds spent near display animals by group and isolation reared guppies over the seven days of the experiment.

nificantly more time near display animals of the same sex than they did near display animals of the opposite sex $(F=14.21, p<.001)$. There was no significant difference, however, in the amount of time that isolation reared Ss spent near display animals of the same sex and the time they spent near display animals of the opposite $\operatorname{sex}(F<1)$.

\section{Discussion}

The results of this investigation are in accordance with the findings of Shelley \& Hoyenga (1966); namely, that group reared Ss spend decreasing amounts of time near display animals over the successive days of the experiment. Their finding that isolation reared
Ss spent increasingly more time near display animals was also corroborated.

These results would seem to be suggestive of an explanation based on a fear or anxiety factor. On Day 1, the Ss were placed in an open field, a situation which has been traditionally used in investigations of anxiety and other forms of emotionality. In such a situation, the group reared Ss seek to reduce their level of anxiety through affiliation with other Ss (Schacter, 1959). This explanation is supported by the fact that group reared Ss displayed a tendency to affiliate with Ss of the same sex as those with which they had been reared. As their anxiety was reduced, they then explored other areas of the open field. This is similar to the behavior displayed by young macaques in Harlow's (1959) work, when they were placed in an open field with fear provoking objects. They initially clung to their surrogate mothers, and then later explored the open field and the fear provoking objects.

For the isolation reared Ss, on the other hand, the display animals were anxiety provoking stimuli during the early sessions, and they spent little time near them. As their anxiety subsided, they began to explore the open field, and spent an increasing amount of time near the display animals. It is interesting to note, however, that the time they spent near display animals was not related to the sex of $S$ or to the sex of the display animal.

\section{References}

ELLIOT, O., \& KING, J. A. Effect of early food deprivation upon later consummatory behavior in puppies. Psychol. Rep., 1960, 6, 391400.

HARLOW, H. The nature of love. Amer. Psychologist, 1958, 13, 673-685.

LINDZEY, G., WINSTON, H. D., \& ROBERTS, L. E. Sociability, fearfulness, and genetic variation in the mouse. J. Pers. soc. Psychol, 1965, 1, 642-645.

SCHACHTER, S. The psychology of affiliation. Minneapolis: University of Minnesota Press, 1959.

SHELLEY, H. P., \& HOYENGA, K. T. Rearing and display variables in sociability. Psychon. Sci, 1966, 5, 11-12. 